\title{
Putative Role of a 70 kDa Outer-surface Protein in Promoting Cell-surface Hydrophobicity of Serratia marcescens RZ
}

\author{
By RONIT BAR-NESS ${ }^{1,2 *}$ AND MEL ROSENBERG ${ }^{1,3}$ \\ The Maurice and Gabriela Goldschleger School of Dental Medicine ${ }^{1}$, the Department of \\ Physiology and Pharmacology ${ }^{2}$, and the Department of Human Microbiology ${ }^{3}$, Sackler Faculty \\ of Medicine, Tel-Aviv University, Ramat-Aviv 69978, Tel-Aviv, Israel
}

(Received 2 February 1989; revised 5 May 1989; accepted 11 May 1989)

\begin{abstract}
Serratia marcescens RZ has been previously shown to possess pronounced cell-surface hydrophobicity, as evidenced by its affinity for hydrocarbons and polystyrene. The present report suggests the involvement of a $70 \mathrm{kDa}$ protein, serraphobin, in this phenomenon. The $70 \mathrm{kDa}$ protein was recovered from both the cell surface and culture supernatant of hydrophobic wild-type cells, but was either totally absent or present in minor quantities in hydrophobicitydeficient mutants. Similarly, loss of hydrophobicity of $\mathrm{RZ}$ cells following growth at $39^{\circ} \mathrm{C}$ was accompanied by loss of the protein. Serraphobin was capable of binding to hexadecane droplets following a brief mixing procedure, and could be desorbed by solidifying and melting the hexadecane phase.
\end{abstract}

\section{INTRODUCTION}

Serratia marcescens is a micro-organism of both ecological and medical importance (Yu, 1979; Sleigh, 1983). Serratia strains adhere avidly to a variety of hydrophobic surfaces such as air/water and oil/water interfaces (Blanchard \& Syzdek, 1978; Hermansson et al., 1982; Kefford et al., 1982; Syzdek, 1982) and to various non-wettable plastics (Rosenberg, 1981). Hydrophobicity of Serratia has been suggested as a survival mechanism in the open environment (Kefford et al., 1982). Similarly, in a recent study of the adhesion properties of 14 clinical $S$. marcescens isolates, all were capable of adhering to hydrocarbons and polystyrene, suggesting a possible role for cell-surface hydrophobicity in initial host colonization (Rosenberg et al., 1986a).

Previous investigations have reported correlations between hydrophobicity in Serratia and production of the pigment prodigiosin (Blanchard \& Syzdek, 1978; Hermansson et al., 1979, 1982; Kefford et al., 1982; Syzdek, 1982). However, non-pigmented clinical strains (Rosenberg et al., 1986a) and mutants (Rosenberg, 1984) may also exhibit intermediate or pronounced hydrophobic surface properties, suggesting the participation of additional factor(s).

In the present study, correlations between hydrophobicity of $S$. marcescens $\mathrm{RZ}$ and the presence and level of a major $70 \mathrm{kDa}$ surface protein (which we have named serraphobin), are reported.

\section{METHODS}

Bacterial strains and growth conditions. S. marcescens strain RZ was originally obtained from R. Zack, Tel Aviv University. Mutant 3162, exhibiting intermediate cell-surface hydrophobicity, and mutant 3164, almost completely devoid of cell-surface hydrophobicity were derived from strain RZ as previously reported (Rosenberg, 1984). The bacteria were maintained on brain heart infusion (BHI) agar (Difco) at $4{ }^{\circ} \mathrm{C}$ and transferred every month. Starter cultures were prepared by inoculating bacteria into tubes containing $2 \mathrm{ml}$ PG broth $[5 \mathrm{~g}$ Bactopeptone, (Difco); $10 \mathrm{ml}$ glycerol, distilled water to one litre] or BHI broth. The tubes were incubated for $24 \mathrm{~h}$ with shaking at 30 or $39^{\circ} \mathrm{C}$. Bacteria were then inoculated into flasks containing $20 \mathrm{ml}$ of PG or BHI broth to an 
initial cell concentration of $5 \times 10^{5} \mathrm{c}$.f.u. $\mathrm{ml}^{-1}$. Following $72 \mathrm{~h}$ incubation at 30 or $39^{\circ} \mathrm{C}$ in a G76 gyratory shaker (New Brunswick Scientific) at 300 r.p.m., samples were taken for c.f.u. determination. Bacteria were harvested by centrifugation at $10000 \mathrm{~g}$, and wet weights were determined.

Spent culture medium. The culture supernatants were sterilized by filtration and stored at $-20^{\circ} \mathrm{C}$ for hexadecane extraction and SDS-PAGE.

Cell pellet extractions. The cell pellets were extracted by $2 \%(\mathrm{w} / \mathrm{v}) \mathrm{SDS} / 5 \%(\mathrm{v} / \mathrm{v}) \beta$-mercaptoethanol as described by McBride et al. (1985). Pellets were washed twice in $0.15 \mathrm{M}-\mathrm{NaCl}$ by centrifugation for $20 \mathrm{~min}$ at $10000 \mathrm{~g}$. Pellets were weighed and subsequently suspended $1: 1(\mathrm{w} / \mathrm{v})$ in $2 \% \mathrm{SDS} / 5 \% \beta$-mercaptoethanol, vigorously agitated on a vortex mixer and boiled for $30 \mathrm{~min}$. The mixtures were then centrifuged for $10 \mathrm{~min}$ at $6000 \mathrm{~g}$. The supernatants were stored at $-20^{\circ} \mathrm{C}$ for SDS-PAGE.

SDS-PAGE. This was performed according to the method of Laemmli (1970). Samples of spent culture medium were diluted in water, correcting for differences in wet weights of cell pellets following growth. Samples of outersurface protein extractions were diluted either $1: 4$ or $1: 8$ in distilled water. Sample buffer $(1$ vol.) containing $40 \mathrm{mmol} 1^{-1}$ dithiothreitol (DTT) was added to 3 vols of sample, and the mixture was boiled for $2 \mathrm{~min}$. Samples $(40 \mu \mathrm{l})$ and standards $(12 \mu \mathrm{l}$; molecular mass markers, $14.2-66 \mathrm{kDa}$, Sigma) were layered on to $7.5 \%$ or $10 \%$ polyacrylamide gels, as indicated. Following electrophoresis at $200 \mathrm{~V}$, protein bands were visualized by staining with Coomassie blue. Since the presence of pigment precluded protein measurement by standard spectrophotometric techniques, the total amounts of protein in each sample were estimated by densitometric comparisons of each lane with that of the molecular mass marker proteins, using a CAMAG TLC Scanner II (Camag, Switzerland); the percentage of serraphobin with respect to total protein was similarly estimated densitometrically.

Hexadecane extraction. Hexadecane extraction of spent culture fluids was carried out essentially as previously described (Rosenberg et al., $1986 \mathrm{~b}$ ). Hexadecane $(0.5 \mathrm{ml})$ was added to $0.5 \mathrm{ml}$ culture supernatant supplemented with $0.5 \mathrm{ml}$ phosphate buffer $\left(44.4 \mathrm{~g} \mathrm{~K}_{2} \mathrm{HPO}_{4}, 14.52 \mathrm{~g} \mathrm{KH}_{2} \mathrm{PO}_{4}\right.$, distilled water to one litre, $\left.\mathrm{pH} 7 \cdot 1\right)$. The aqueous hydrocarbon mixtures were then vortexed for $2 \mathrm{~min}$ on a Thermolyne Maxi Mix flat-top mixer (Sybron, Dubuqe, Iowa, USA) at room temperature. Following phase separation, the lower aqueous phase was removed carefully using a Pasteur pipette to another test tuie containing an additional $0.5 \mathrm{ml}$ hexadecane, and the procedure was repeated. Following four such extraction cycles the final lower aqueous phase was stored at $-20^{\circ} \mathrm{C}$ for SDSPAGE. Half-strength phosphate buffer $(0.25 \mathrm{ml})$ was added to the hexadecane portions. The mixtures were cooled to $0{ }^{\circ} \mathrm{C}$ until solidification of the hexadecane was complete. The test tubes were then incubated at $30^{\circ} \mathrm{C}$ until the hexadecane melted. The test tubes were cooled and heated in this manner three consecutive times; the final mixture was stored at $-20^{\circ} \mathrm{C}$ for at least $18 \mathrm{~h}$. Prior to SDS-PAGE, the test tubes were allowed to reach room temperature, and samples for SDS-PAGE were removed from the lower aqueous phase.

Cell-surface hydrophobicity. Bacterial hydrophobicity was determined by adhesion to hexadecane (Rosenberg, 1981, 1984). To $1.4 \mathrm{ml}$ bacterial suspension, washed and suspended in half-strength phosphate buffer, $0.2 \mathrm{ml}$ hexadecane was added and the mixtures vortexed in semi-micro polystyrene disposable cuvettes for $60 \mathrm{~s}$. Following phase separation, the absorbance of the lower aqueous phase at $400 \mathrm{~nm}$ was determined. Adhesion is expressed as the percentage decrease in turbidity of the lower aqueous phase following mixing, compared to that of the initial cell suspension (Rosenberg, 1984).

\section{RESULTS}

Hydrophobic Serratia marcescens RZ cells, grown at $30^{\circ} \mathrm{C}$ on $\mathrm{PG}$ or BHI medium, produced an extracellular protein (serraphobin) with a molecular mass of approximately $70 \mathrm{kDa}$, which was one of the major proteins ( $25 \%$ of total supernatant protein) recovered from the culture supernatant (Fig. 1, lane 1). Serraphobin appeared to be totally absent in spent culture media of non-hydrophobic mutant 3164 (Fig. 1, lane 2) and non-pigmented mutant 3162 (Fig. 1, lane 3). A second supernatant protein of about $50 \mathrm{kDa}$ was present in wild-type RZ cells and mutant 3164 cells (Fig. 1, lanes 1, 2), but was absent from spent culture media of mutant 3162 (Fig. 1, lane 3). The absence of this protein may be related to loss of pigmentation in mutant 3162 .

In order to determine whether serraphobin is located on the outer surface of RZ cells, treatment with $2 \% \mathrm{SDS} / 5 \% \beta$-mercaptoethanol, as described by McBride et al. (1985), was employed (Fig. 1, lanes 4-6). Serraphobin was extracted in relatively large amounts $(5 \%$ of total protein, lane 4) from wild-type RZ cells, as opposed to no appreciable amounts in nonhydrophobic 3164 cells (lane 5), and minimal quantities $(0.4 \%$ of total protein) in partially hydrophobic 3162 cells (lane 6). Serraphobin was also extracted from wild-type RZ cells following $1 \%$ SDS treatment (data not shown), as described by Jenkinson (1986). Thus, this protein appears to be a cell-surface component of the outer surface of RZ. 


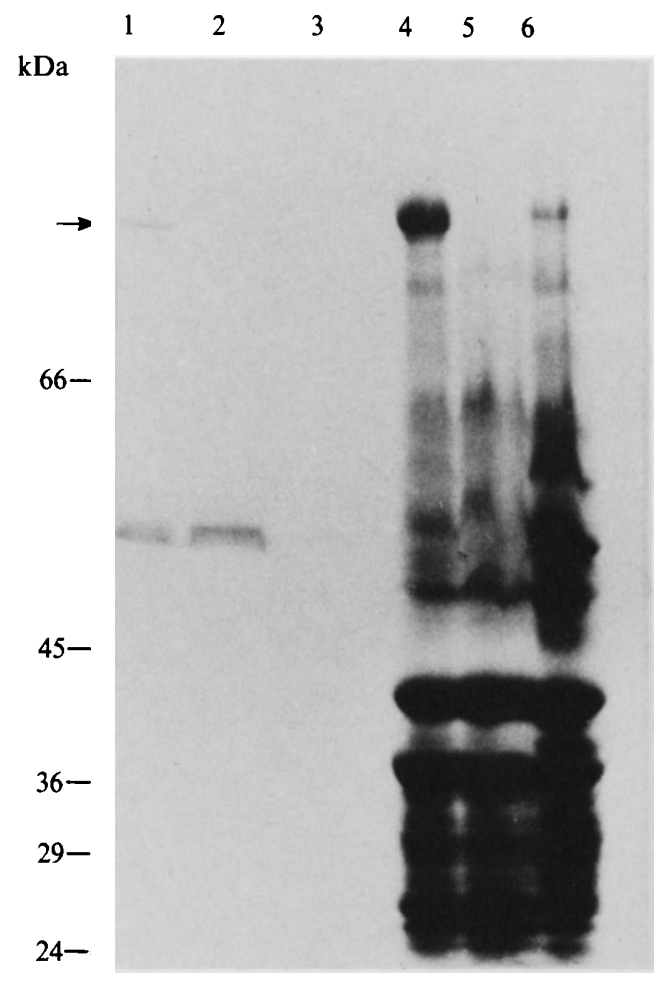

Fig. 1. SDS-PAGE of culture supernatants and outer-surface protein extracts following growth at $30^{\circ} \mathrm{C}$ in BHI broth. Culture supernatant samples were diluted with water to correct the differences in wet weights of pellets following growth: $\mathrm{RZ}, 46.9 \mathrm{mg} \mathrm{ml}^{-1}$; mutant $3164,29.1 \mathrm{mg} \mathrm{ml}^{-1}$; mutant 3162 , $40.6 \mathrm{mg} \mathrm{ml}^{-1}$. About $2 \mu \mathrm{g}$ of protein of each sample was loaded onto a $7.5 \%$ polyacrylamide gel. Outersurface proteins were extracted from washed cell suspensions, as described in Methods. Samples were diluted $2 \cdot 5$-fold in water. Approximately $250 \mu \mathrm{g}$ of protein of each sample was loaded onto the gel. Protein bands were visualized by Coomassie blue staining. Adhesion to hexadecane was $76 \%$ for RZ cells, $0 \%$ for 3164 cells, and $28 \%$ for strain 3162 . Lanes: culture supernatants of RZ (lane 1), 3164 (lane 2) and 3162 (lane 3); outer surface protein extracts of RZ (lane 4), 3164 (lane 5) and 3162 (lane 6). Serraphobin is indicated by the arrow. Molecular mass standards: bovine serum albumin ( $66 \mathrm{kDa})$; ovalbumin $(45 \mathrm{kDa})$, glyceraldehyde-3-phosphate dehydrogenase $(36 \mathrm{kDa})$, carbonic anhydrase $(29 \mathrm{kDa})$, trypsinogen $(24 \mathrm{kDa})$ and trypsin inhibitor $(20 \mathrm{kDa})$.

Serraphobin, released from the cell surface, exhibited affinity for hexadecane droplets (Fig. 2). Mixing with hexadecane removed $92 \%$ of the protein from the aqueous phase (lane 2). Its partitioning to the oil/water interface could be demonstrated by subsequent desorption (lane 3) following solidification of the hexadecane droplets at below $18^{\circ} \mathrm{C}$, a technique recently proposed for separation of amphipathic proteins (Rosenberg et al., 1986b). Another major culture supernatant protein of about $42 \mathrm{kDa}$ was also eluted by hexadecane. This $42 \mathrm{kDa}$ protein was also present in the non-hydrophobic mutant 3164 , and remained following growth at $39^{\circ} \mathrm{C}$.

Previous studies have shown that cell-surface hydrophobicity in strain $\mathrm{RZ}$ and other $S$. marcescens isolates is lost when the cells are grown at temperatures above $38^{\circ} \mathrm{C}$ (Rosenberg et al., $1986 a$ ). Fig. 3 compares the proteins extracted from the cell surfaces of RZ, 3162 and 3164 grown at $39^{\circ} \mathrm{C}$. Serraphobin was found neither in cell-surface extracts (Fig. 3, lanes 2-4), nor in the spent culture medium (not shown) of any of the strains.

\section{DISCUSSION}

The present study suggests the involvement of a $70 \mathrm{kDa}$ surface protein, serraphobin, in mediating cell-surface hydrophobicity in $S$. marcescens RZ. Serraphobin was recovered from 


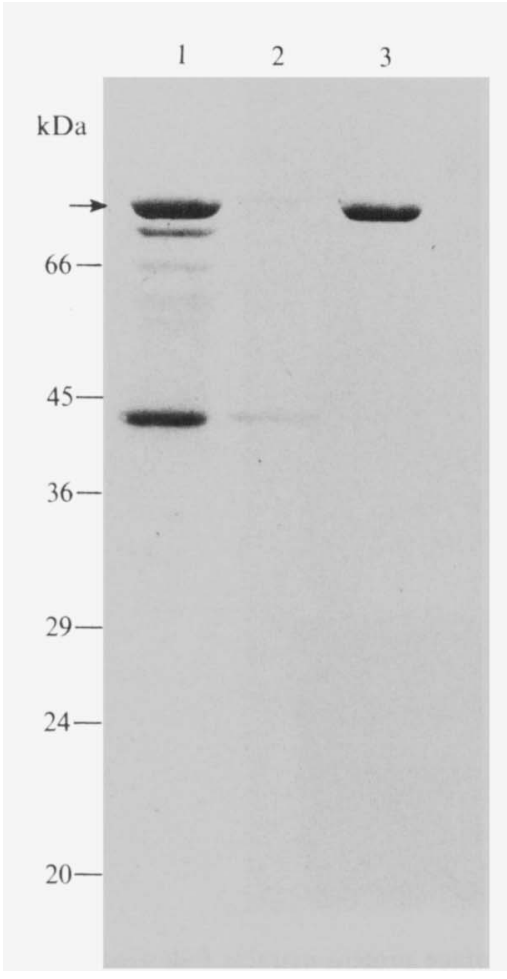

Fig. 2

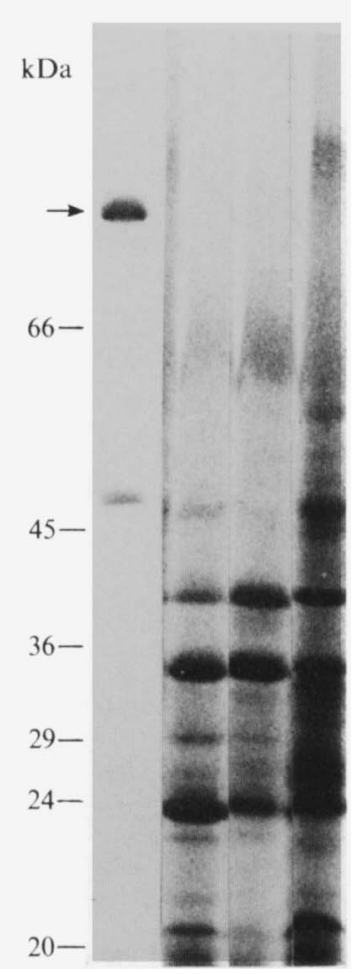

Fig. 3

Fig. 2. SDS-PAGE of culture supernatant of $S$. marcescens $\mathrm{RZ}$ following growth at $30^{\circ} \mathrm{C}$ on PG medium, before and after hexadecane extraction and desorption. Samples were applied onto a $10 \% \mathrm{gel}$. Protein bands were visualized by Coomassie blue staining. Adhesion of washed cells to hexadecane was $71 \%$. Lanes: $1, \mathrm{RZ}$ culture supernatant prior to hexadecane extraction (about $10 \mu \mathrm{g}$ protein was loaded onto the gel); $2, \mathrm{RZ}$ culture supernatant following $8 \mathrm{~min}$ mixing with hexadecane; 3 , desorption following solidification and melting of the upper phase following mixing with hexadecane. Twenty-five percent of the adsorbed serraphobin was recovered by the desorption procedure, as determined by densitometry. Serraphobin is indicated by the arrow. Molecular mass standards, see Fig. 1.

Fig. 3. SDS-PAGE of cell-surface extracts following growth at $39^{\circ} \mathrm{C}$. Samples of cell-surface extracts following growth at $39^{\circ} \mathrm{C}$ (approx. $20 \mu$ g protein per sample) were applied to a $7.5 \%$ gel: lane $2, \mathrm{RZ}$; lane 3,3164 ; lane 4,3162 . As control, culture supernatant of $R Z$ cells grown at $30^{\circ} \mathrm{C}(2 \mu \mathrm{g}$ protein) was applied to lane 1 . Protein bands were visualized by Coomassie blue staining. Adhesion to hexadecane was less than $10 \%$ for all strains. Serraphobin is indicated by the arrow. Molecular mass standards, see Fig. 1.

both the cell surface and culture supernatant of hydrophobic wild-type cells, but was absent in non-hydrophobic mutant 3164 , and present in minor quantities on the surface of partially hydrophobic 3162 mutant cells. Similarly, loss of hydrophobicity of RZ cells following growth at $39^{\circ} \mathrm{C}$ was accompanied by loss of serraphobin. Serraphobin was capable of binding to the hexadecane/water interface following a brief mixing procedure, and could be desorbed by solidifying the hexadecane phase. Preliminary data (not shown) show a correlation between serraphobin production and cell-surface hydrophobicity in several clinical $S$. marcescens isolates.

Recent studies have shown that cell-surface hydrophobicity in Serratia strains is more complicated than previously anticipated, involving an interplay of various 'hydrophobins' (hydrophobicity-promoting factors) and 'hydrophilins' (hydrophobicity-reducing components). For example, whereas earlier investigations of hydrophobicity in $S$. marcescens suggest that prodigiosin is chiefly responsible for this phenomenon, more recent studies have demonstrated 
that non-pigmented isolates and mutants can also exhibit hydrophobic properties (Blanchard \& Syzdek, 1978; Hermansson et al., 1979, 1982; Rosenberg, 1981, 1984), suggesting that additional hydrophobins are involved. Based on the present data, serraphobin appears to be a hydrophobin in RZ cells. Conversely, the potential role of cell-surface components which reduce hydrophobicity must also be considered. For example, serratamolide, an amphipathic cellsurface component of some $S$. marcescens strains (including RZ) acts as a hydrophilin (Bar-Ness et al., 1988).

Investigations are presently under way to further characterize serraphobin, its distribution in clinical Serratia strains, and its role in promoting adhesion of $S$. marcescens to hydrophobic surfaces.

The authors are grateful to I. Oshry for assistance with the densitometry measurements. The excellent technical assistance of Y. Mazor and L. Maman, and the editorial help of R. Lazar, are gratefully acknowledged.

This research was carried out in the Alpha Omega Research Laboratories, School of Dental Medicine, Tel Aviv University, and supported by grant no. 86-00263 from the United States-Israel Binational Science Foundation (BSF), Jerusalem, Israel.

\section{REFERENCES}

Bar-Ness, R., Avranamy, N., Matsuyama, T. \& ROSENBERG, M. (1988). Increased cell surface hydrophobicity of a Serratia marcescens NS 38 mutant lacking wetting activity. Journal of Bacteriology 170 , 4361-4364.

Blanchard, D. C. \& Syzdek, L. D. (1978). Seven problems in bubble and jet drop researches. Limnology and Oceanography 23, 389-400.

Hermansson, M., KJelleberg, S. \& Norkrans, B. (1979). Interaction of pigmented wild type and pigmentless mutant of Serratia marcescens with lipid surface film. FEMS Microbiology Letters 6, 129-132.

Hermansson, M., KJelleberg, S., Korhonen, T. K. \& Stenstrom, T. A. (1982). Hydrophobic and electrostatic characterization of surface structures of bacteria and its relationship to adhesion to an airwater interface. Archives of Microbiology 131, 308312.

JENKINSON, H. F. (1986). Cell-surface proteins of Streptococcus sanguis associated with cell hydrophobicity and coaggregation properties. Journal of General Microbiology 132, 1575-1589.

KefFord, B., KJelleberG, S. \& Marshall, K. C. (1982). Bacterial scavenging: utilization of fatty acids localized at a solid-liquid interface. Archives of Microbiology 133, 257-260.

LAEMMLI, U. K. (1970). Cleavage of structural proteins during the assembly of the head of bacteriophage T4. Nature, London 227, 680-685.

MCBride, B. C., Morris, E. J. \& Ganeshkumar, N.
(1985). Relationship of streptococcal cell surface proteins to hydrophobicity and adherence. In Molecular Basis of Oral Microbial Adhesion, pp. 85-93. Edited by S. Mergenhagen \& B. Rosan. Washington, DC: American Society for Microbiology.

ROSENBERG, M. (1981). Bacterial adherence to polystyrene: a replica method of screening for bacterial hydrophobicity. Applied and Environmental Microbiology 42, 375-377.

ROSENBERG, M. (1984). Isolation of pigmented and non-pigmented mutants of Serratia marcescens with reduced cell surface hydrophobicity. Journal of Bacteriology 160, 480-482.

Rosenberg, M., Blumberger, Y., Judes, H., BARNess, R., Rubinstein, E. \& Mazor, Y. (1986a). Cell surface hydrophobicity of pigmented and nonpigmented clinical Serratia marcescens strains. Infection and Immunity 51, 932-935.

Rosenberg, M., Zosim, Z., Regimov, N. \& Eli, I. $(1986 b)$. Separation of amphipathic proteins based on adsorption to hexadecane: water interfaces. Preparative Biochemistry 16, 133-141.

Sleigh, J. D. (1983). Antibiotic resistance in Serratia marcescens. British Medical Journal 287, 1651-1653.

SyzDEK, L. D. (1982). Concentration of Serratia in the surface microlayer. Limnology and Oceanography 26, 961-964

YU, V. L. (1979). Serratia marcescens - historical perspective and clinical review. New England Journal of Medicine 300, 887-891. 